\title{
The Films of Julian Schnabel
}

\author{
By Alex Britton \\ Spring 2011 Issue of KINEMA

\section{CHARACTERIZATION, REVISIONISM AND MISREPRESENTATION IN THE FILMS OF JULIAN SCHNABEL}

A few years ago after viewing the 2007 film The Diving Bell and the Butterfly, the third film by contemporary director and (former) star painter Julian Schnabel, a friend of New York Review of Books writer Sanford Schwartz prophetically announced to the critic, "Apparently it's easier to make a great movie than a great painting." (1) Indeed, Schnabel's ascension to art stardom has taken a truly enigmatic path. Initially conjuring his success as a painter within the elitist landscape of the late $20^{\text {th }}$ century New York City art market, today we find Schnabel strutting down the red carpet of the Cannes and Toronto international film festivals after writing and directing three films while armed with seemingly zero experience in the field of filmmaking or screenwriting.

As a painter, Schnabel's work is largely classified as "Neo-Expressionist", belonging to Postmodernism's timely rediscovery of the ancient medium's equally symbolic and commercial presence. Schnabel's painting style has been compared to artwork by contemporaries from the United States, Germany and Italy on the basis of a unified aesthetic narrative which combines "pastiche", or collage with brushstrokes that appear to signify representations of the "figurative" as it emerges from the dust of abstraction. ${ }^{(2)}$ As the embodiment of a generation staking a claim in the New York soil once dominated by the forces of Modernism, Pop culture, and Andy Warhol, new talents beginning to populate the 1980s art scene, painters like Anslem Keifer and Francesco Clemente, accompanied Schnabel in the crusade to re-introduce an art historical context to a market that had apparently lost its way. ${ }^{(3)}$ However, these artists, regardless of how enlightening or refreshing their work was and still is, simply reaffirmed a pretentious corporate-fuelled New York art world of its own aimless fantasy to buy, collect, and inevitably re-sell paintings and other fine art objects for solely monetary reasons. ${ }^{(4)}$ Schnabel himself perhaps represents this phenomenon of history best. A painter with celebrated ties to New York's high-society Pace Gallery at present day, critics and art historians are quick to point out the role of New York gallery owner and art dealer Mary Boone in nourishing the legend of Schnabel the artist. ${ }^{(5)}$ Subsequently, art collectors Charles and Maurice Saatchi (who purchased Schnabel paintings in bulk) had heavy hands in transforming the Postmodern art market into a neo-conservative system tailored for a character like Schnabel, a man harbouring conflicting levels of talent and self assurance, to succeed financially, albeit perhaps not critically. ${ }^{(6)}$

Poet and avant-garde critic René Ricard made his mark on Postmodern New York with two critical essays written for Artforum magazine in the early 1980s, the first of which titled Not About Julian Schnabel specifically targeted a defunct art industry for breathing power into overnight sensations like Schnabel. ${ }^{(7)}$ Ricard's next article, the infamous essay Radiant Child, elaborated on the notion of commercial inflation producing undeserved art stars, and this compelling stream of consciousness exposition notably introduced the world to the misunderstood and tragic painter Jean-Michel Basquiat (1960-1988). ${ }^{(8)}$ In Radiant Child, Ricard angrily retorts, "We are no longer collecting art, we are buying individuals." ${ }^{(9)}$

At this point we must fast forward out of the cultural turbulence of the 1980s and back to the revisionist bliss of the early $21^{\text {st }}$ Century, where our spotlighted Schnabel has claimed his throne as the adept, Oscarnomination-worthy filmmaker of Before Night Falls (2000) and The Diving Bell and the Butterfly. Previously recognized as a controversial Neo-Expressionist painter from the turn of the millennium, it is most puzzling that Schnabel can seemingly will the praise of his films at the snap of a finger, and what is far more intriguing is that his films are likely deserving of such praise. New York City review writer Schwartz proposes "that in these films Schnabel is less finding or fulfilling himself than creating additional ways to handle themes he has presented with real power, though more ambiguously, and sometimes all too sketchily, in his paintings." (10)

Schnabel's filmmaking career began in 1996, as he wrote, directed, and produced the film Basquiat. On the surface the film is impressive in its vibrant recreation of 1980s New York, and the DVD proudly boasts a 
"Two Thumbs Way Up!" and "One Of The Years Best!" from Siskel 86 Ebert on its front cover. However, Basquiat is clearly a less polished film than Schnabel's later successes in terms of screenwriting and narrative structure, and Schwartz identifies it as having "been something of a trainer film" for the inexperienced filmmaker. ${ }^{(11)}$

Yet apart from any noticeable structural issues in Basquiat, the film's overall content and storyline are extremely problematic as they contribute to an arguably massive misrepresentation of the brilliant painter, Basquiat. Originally earning acclaim as the street artist SAMO, Basquiat's whirlwind painting career saw the talented 20-year-old ally himself with art world superstars Andy Warhol and Keith Haring, and warranted bids in the tens of thousands for his work in multiple European markets before his premature death in 1988 at age $27 .{ }^{(12)}$

Interestingly, Schnabel and Basquiat's discovery of stardom as painters parallelled one another, both in time line and style. While harsh, expressionistic textures frequented the paintings of most Postmodern painters, the narrative objectivity of Schnabel and Basquiat's work is also comparable, as they mutually convey an implicit fascination with art history and figurative representation. ${ }^{(13)}$ Schnabel's 1996 film serves as a biographic tribute to the life of Basquiat, and although some critics sang its praises, it is evident the film presents issues in representation that contribute to an inaccurate portrayal of the late painter. Moreover, it is somewhat suspicious that Schnabel would take on the roller coaster existence of Basquiat for the material of his first film, as the men were essentially in competition and unassociated with one another in reality. New York Times film reviewer Holland Carter draws attention to Basquiat's corrupted legacy, which Schnabel unmistakably participated in, stating, "Jean-Michel Basquiat did a lot of people a lot of favours. He gave Julian Schnabel a film. He gave a 50-something Andy Warhol acceptance by association into the art world of the 80s. And, in the view of some, he gave a fundamentally elitist and racist New York art world a riskfree chance to embrace a black artist." ${ }^{(14)}$ As there are blatantly many similarities and differences existing between Schnabel and Basquiat, why was Schnabel so concerned with giving the world the narrative film version of Basquiat's life?

Schnabel's second feature film, Before Night Falls, is a stunning and engaging work that exceeds the usual territory of a filmmaker's young career, and even received a best actor Oscar nomination for Javier Bardem's performance in the lead role. Again, Schnabel has chosen the non-fiction life story of the Cuban writer and poet Reinaldo Arenas as the basis of his film's narrative, a selective trend that permeates throughout Schnabel's screenwriting from his earliest Basquiat to his latest The Diving Bell and the Butterfly. In Before Night Falls, we are invited to relive the chaotic life of Arenas as he experiences the wonders and horrors of the Cuban Revolution occurring in the mid $20^{\text {th }}$ Century. Arenas in life wrote feverishly, and his work is described as anti-establishment magic realism that at times borders on the surreal. ${ }^{(15)}$

Evidenced in his writing, Arenas was obsessed with the symbolic value of his identity as it pertained to the political and ideological shift unfolding within the Cuban Government, and as an outspoken homosexual undeniably addicted to sex, he broadcasted his non-conformist queer attitudes in his published work as a psychological counter attack against a regime he thoroughly believed to be despotic. ${ }^{(16)}$ Schnabel's film takes its title from Arenas' memoirs published in 1993, and assuming the film is based on the Cuban intellectual's own personal reflections, Before Night Falls facilitates issues identical to that of Schnabel's Basquiat, as it brazenly takes the liberty of transforming the life of a Spanish literary great into narrative vehicle designed for passive cinematic consumption. In the article "Global Arenas: Narrative and Filmic Translation of Identity", analysis by Jacqueline Loss addresses Schnabel's unforgiving need to tamper with Cuban and American history. ${ }^{(17)}$ Loss writes:

Who comprises the world for which Schnabel believes he has rescued the Cuban writer, who died little more than a decade ago? Is it the film critics who, having admittedly never heard of Arenas before the film, dismiss him as less talented than painter Jean-Michel Basquiat, subject of Schnabel's 1996 film? Is it the New York artists whose creative tourism had somehow sidestepped Arenas? Or is it perhaps the multiplex cinemas that favor Hollywood, leaving screens for a handful of independent productions? Schnabel's world diminishes the contributions of those who for many years have read Arenas in Spanish as well as in French, German, Portuguese, and English translations. ${ }^{(18)}$ 
In 2007, Schnabel's filmmaking momentum continued with the critically successful The Diving Bell and the Butterfly, winner of best picture at the Golden Globe awards. In Schnabel's most touted film to date, experimental style and an elite production team (the screenplay is written by Ronald Harwood, the accomplished screenwriter behind The Pianist, 2002) combine to reenact the tale of Frenchman Jean Dominique Bauby, a magazine editor for Paris' Elle that succumbs to a life altering stroke while in his 40s. This medical incident left Bauby in a paralyzed state known as locked-in syndrome, whereby one's mind still functions at full capacity while the body remains almost entirely useless.

As an ambitious and philosophical man, Bauby embraced the opportunity to adapt to his condition, and with the guidance of two young health care workers, adopted a language to communicate by simply blinking his left eye, essentially his only remaining physical ability. The former magazine writer then uses this language system to spell out, letter by letter, his memoirs to one of his nurses, and like Before Night Falls, its title is recycled in Schnabel's film. At this point in his filmmaking career, Schnabel has exclusively generated films dealing with real life people of extreme accomplishment, and he is more or less rubbing his talent for visual composition and historic re-appropriation in the faces of any audience or critic willing to challenge him. For much has been written of Schnabel's unbearably pompous personality as a painter, and to see him at present redefining the meaningful lives of these three men in his films is quite paradoxical. Schwartz feels that with The Diving Bell, Schnabel's filmmaking career has proven the former painter has "finally found his footing" as an artist, and attributes this to his choice of narrative content. ${ }^{(19)}$ Schwartz claims, "The movie is about a patient's transformation of himself as he lies in a hospital bed; and it has been made by someone who, with a perhaps related kind of strength, is similarly extending himself."(20)

Yet however far Schnabel's evolution as an artist has come is a separate topic, for we must instead question his fascination with producing historical film, as it threatens the integrity and enduring legacy of each of the aforementioned characters through similar revisionist misrepresentations. As one of Bauby's real-life friends exclaims when asked how he received the film, "It (the movie) is not the story of my friend... It is a story for Hollywood." (21)

As we analyze Schnabel's three films, it is evident this filmmaker gravitates toward narratives and characters stemming from the late $20^{\text {th }}$ Century. Furthermore, as each film stylizes and emblematizes its protagonist within the conventions of narrative filmmaking, this paper will conclude Schnabel's films problematically renegotiate the position of Basquiat, Arenas, and Bauby within contemporary cultural thought, and subsequently damage the representation of these men's identities within the scope of history. Aiding the study of Schnabel's inherently revisionist narrative constructions, the following analysis will illuminate the process and methods of characterization performed by each film's protagonist, in effect elaborating on the sameness of these characters as products of re-appropriation and misrepresentation.

\section{Basquiat}

In the view of many, beginner's luck arrived in time to rescue Schnabel's career in 1996 with his first film Basquiat. However, those engaged in academically-oriented fields, rather than glitzy Hollywood circles, immediately saw through Schnabel's cinematic gimmickry. ${ }^{(22)}$ Leonhard Emmerling's research-based biography of the same name as Schnabel's inaugural film, Basquiat, not only blasts the filmmaker for irreparably diminishing the life story of one of New York's brightest young painters into a pragmatic, drug-induced romp through Manhattan, yet his analysis also attributes these narrative results to a sketchy, misconceived portrayal of Basquiat from a characterization standpoint. ${ }^{(23)}$

Emmerling writes, "With his 1996 film Basquiat, Julian Schnabel completed the process of transforming JeanMichel Basquiat into myth and permanently robbing him of his relevance. Schnabel's reduction of Basquiat to a colour-spurting genius in a bathrobe, a smart young black guy who unfortunately took too many drugs and had the bad luck to die from them, once again reproduces the cliché of the tragically failing artist."(24) With the underrated Jeffrey Wright starring in the lead role as Basquiat, and David Bowie lending his overbearing presence to the supporting role of Andy Warhol, Basquiat's shortcomings are not so much an issue of casting as they are of narrative development, and ultimately, the filmic re-representation of each character. As we attempt to trace Basquiat's flaws to a dismissive rendering of characterization on Schnabel's part, acclaimed film theorist David Bordwell offers us insight, explaining how stylistic differentiations in character often function to expose a director's narrative formula. ${ }^{(25)}$ 
In Film Art: An Introduction, Bordwell defines characterization as belonging to either an "individualized" or "stylized" performance by the actor, and draws on the early Soviet Cinema concept of "typage"; a realism governing device confining one's character to an easily recognizable social class, as having a major influence on the realistic acting we see in narrative filmmaking to this day. ${ }^{(26)}$ Our much- referenced article "The Nerve and The Will" by Schwartz discusses Wright's re-enactment of Basquiat's personality, deeming it too introverted and ambiguous to warrant any critical reevaluations of the painter's short life. ${ }^{(27)}$ Schwartz proposes, "Whether because of Jeffrey Wright's subdued performance as Basquiat - he often seems to be retreating into himself or responding only by angling or twitching his hands and body - or to Schnabel's having taken on too much material (the screenplay is solely his), the movie is more like a careful and sweet-tempered illustration than a penetratingly original view." Most interesting is Schwartz's description of Wright as "retreating into himself", or as "angling or twitching", for within the stylistic parameters outlined by Bordwell, such actions should contribute to a "stylized" performance. ${ }^{(28)}$

Exemplifying his claims, Bordwell cites the famous German Expressionist film The Cabinet of Dr. Caligari (1922) in which the stylized, "dance-like portrayal of the somnambulist Cesare makes him blend in with the graphic elements of the setting." (29) Schnabel's Basquiat shares little in common with German Expressionist film, however both Schnabel and Basquiat's painting styles are undoubtedly linked to the Expressionist and abstract paintings coming out of Europe in the early $20^{\text {th }}$ Century. As Basquiat tirelessly flaunts oversized Schnabel canvases and fake Warhol and Basquiat paintings throughout its sets and mise-en-scene, perhaps Wright's "subdued" performance was promoted intentionally by Schnabel as a way to stylistically integrate his protagonist within the "colour-spurting" urban environment of New York City. With Emmerling summarizing Basquiat's life as, "Driven by an insatiable hunger for recognition, fame and money, wavering between megalomania and insurmountable shyness, plagued by self-doubt and self-destructive impulses," Wright's ambiguously introverted portrayal in the lead role is likely more accurate than most are willing to accredit. ${ }^{(30)}$ However, the numerous unfulfilled voids left in the film's narrative structure and the oversimplified delineation of the legendary painter's demise will not be forgiven by friends and fans of Basquiat any time soon.

\section{Jeffrey Wright in Basquiat}

In Basquiat, Schnabel wastes no time in manipulating both the representation of the title character and art history itself, beginning with a montage sequence juxtaposing the opening credits with a dreamlike depiction of young Basquiat and his mother perusing New York City's Museum of Modern Art. Culminating with a close-up of the child as he adorns a shimmering golden crown, the sequence appears to announce Basquiat's claim to art world royalty, or at least so it seems in Schnabel's view. Immediately following the opening sequence, we hear the gravelly voice of actor Michael Wincott as he recites important lines from René Ricard's Radiant Child. Schnabel has cast Wincott in the role of Ricard, and as the unconventional writer is unanimously recognized as the man spearheading Basquiat's rise to fame, the filmmaker fittingly uses Ricard's powerful writing in Radiant Child to kick-off his film's narrative.

The setting appears to be Central Park, where we watch Ricard scribble thoughtfully in his notebook while Wincott provides off-screen narration, words from Radiant Child, and we assume Schnabel is suggesting this scene to represent the very moment Ricard composed his influential essay. Biographer Emmerling cites the significance of Ricard's role in catapulting Basquiat to art-stardom, explaining, "With the following words, Ricard placed Basquiat's work within a larger tradition of art history: 'If Cy Twombly and Jean Dubuffet had a baby and gave it up for adoption, it would be Jean-Michel.'"(31)

In addition, Emmerling echoes many of Ricard's ideas in his own description of Basquiat's identity, notably stating, "His life, its feverishness, his meteoric rise and early death all lend themselves fabulously to the myth-making of Basquiat as the epitome of a nobly failed genius, the artist as exemplary outsider... This image has been shaped by painters like Vincent van Gogh, who was denied recognition in his lifetime and who mortally wounded himself as a 'suicide by society'... The same cliché was also served by the fate of Jackson Pollock." (32) That is, Emmerling links Basquiat's free fall from celebrity to the same cruel industry that destroyed the lives and careers of painters Van Gogh and Pollock, labelling them too "distant" from society to make any serious cultural or aesthetic contribution. ${ }^{(33)}$ This very concept, that of the failed artist in life garnering critical and economic success from beyond the grave, is precisely the message delivered by Ricard with Radiant Child, in his way defining the inflation-plagued status of the Postmodern art market. 
In both Radiant Child and Schnabel's Basquiat, Ricard's narrative voice amplifies:

Everybody wants to get on the Van Gogh Boat. There is no trip so horrible that someone won't take it. Nobody wants to miss the Van Gogh Boat. The idea of the unrecognized genius slaving away in a garret is a deliciously foolish one. We must credit the life of Vincent van Gogh for really sending that myth into orbit... We're so ashamed of his life that the rest of art history will be retribution for van Gogh's neglect. No one wants to be part of a generation that ignores another van Gogh. ${ }^{(34)}$

All in all, Schnabel has agreeably woven Ricard's writing into the fabric of his narrative representation of Basquiat, and has done so in a way that reflects Emmerling and Ricard's understanding of the painter's identity. Yet the potential issue we are targeting is the recreation of primary sources in Basquiat, specifically, Schnabel's recreation of Ricard's literature, which he has done with a surprising level of class and accuracy. However, the overall role of Ricard in Basquiat is disengaged from reality. For example, Ricard in the film takes his vision of Basquiat as art-world-sensation one step further, physically parading him to the right parties and introducing him to the right people, when in actuality, according to Emmerling, these actions were carried out by a man named Diego Cortez, an artist seeking acceptance in New York who "developed himself into a kind of broker for Basquiat."(35)

Indeed, as the real story goes, Ricard did all he could to promote the painter from a distance, yet had no part in any hands-on schmoozing, and thus the memorable scene in Basquiat where Ricard drunkenly calls out the artist and his new cohorts over dinner can only be pure and utter fiction, while Cortez in reality is on record as saying his informal break with Basquiat left him feeling "as hurt and betrayed as I ever had by any artist.."(36)

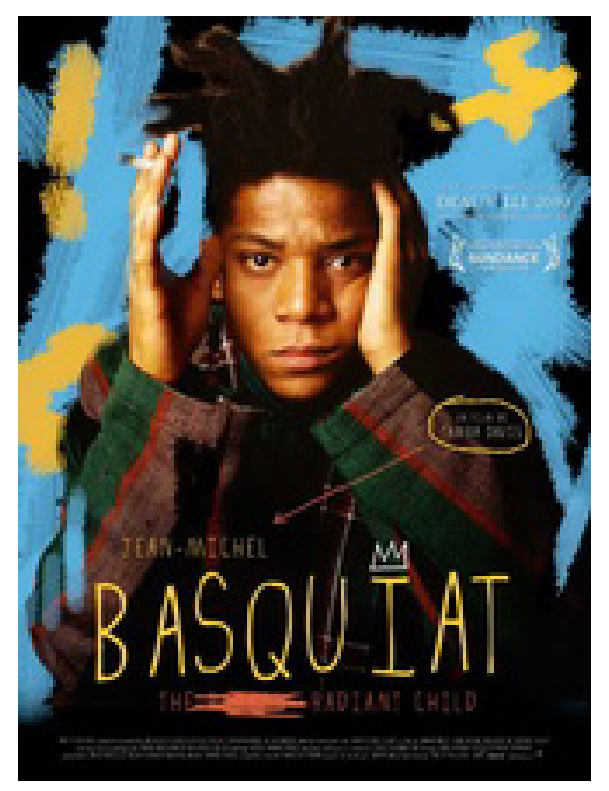

Figure 1: Basquiat (Julian Schnabel, 1996, publicity poster)

Basquiat and Ricard were not the only ones vulnerable to Schnabel's range of misrepresentation. The portrayal of Andy Warhol, and in particular his meaningful friendship with Basquiat, is underdeveloped, rather than distorted as in Schnabel's revisionist interpretation of Ricard's character. While watching Wright and Bowie's antics in the roles of Basquiat and Warhol is enjoyable to a degree, as one gathers further knowledge of the men's history of working together, it is evident that certain elements of their relationship were downplayed by Schnabel. Basquiat does its best to illustrate Basquiat, Warhol and Clemente's painting collaboration of the mid-80s, providing scenes of the two artists enigmatically working side by side, although Clemente is strangely ignored altogether in the film, and also some of Warhol and Basquiat's most compelling interactions with one another have gone completely unrecognized, such as their competitive painting of each 
others portraits. ${ }^{(37)}$

Yet overall, Schnabel's most offensive misrepresentation manifests in his one-dimensional portrayal of Basquiat as a "Bum" or "Junky" at the film's conclusion. Scholars and researchers that have investigated Basquiat's career agree the man suffered severely from drug addiction and that it eventually took his life, yet prior to his death the man had achieved unparalleled levels of success and fame despite being stereotyped as a tragic and fatalistic artist. ${ }^{(38)}$ Basquiat owned luxurious properties around the world, in particular a ranch in Maui that he often visited before passing away, and was known for partying with famous artists at exotic locales across the globe. ${ }^{(39)}$ Of course, Schnabel has no desire to incorporate these luxuries of Basquiat's life into his film's narrative, as it would conflict with his preferred representation of the painter as a borderline homeless person stumbling around New York on drugs.

\section{Before Night Falls}

Schnabel's next film Before Night Falls is an excellent work of narrative filmmaking, easily superior to his first film Basquiat. The cinematography and composition in the film are remarkable, and Schnabel deserves our praise for stylistically transforming Mexico into Arenas' Cuban stomping grounds. Mentioned earlier, Before Night Falls is most impressive for Javier Bardem's powerful characterization of the author Arenas, his performance realistically fleshing out a man who may have remained inaccessible to most of the English speaking world were it not for Schnabel's film. However, despite the quality of Bardem's acting, some researchers familiar with Arenas' work prior to the release of Before Night Falls were unimpressed with Schnabel's Hollywood-style re-enactment of Arenas' life story; writer Jon Hillson complains Bardem and Schnabel's film represent a "stylized, sanitized confection that Arenas becomes." (40)

Yet we all know Academy Award Nominations aren't given out for free, and above all, critics like Hillson are more so put off by Schnabel's sketchy narrativization of both Cuban history and the life of Arenas than Bardem's noteworthy performance. In understanding how Bardem executed such a memorable, and what seems realistic characterization of Arenas, statements made by theorist Bordwell regarding "stylized" versus "individualized" protagonists help to reinforce our discussion. ${ }^{(41)}$ Bordwell explains, "As a first approximation, we can consider performance styles along two dimensions. The performance will be more or less individualized, and it will be more or less stylized. Often we have both in mind when we think of a realistic performance: It will create a unique character, and it will not seem too exaggerated or too underplayed." ${ }^{(42)}$

Regarding Bardem's portrayal of Arenas, one would have to think it qualifies mainly as an "individualized" performance, as the actor's immersion in the role leaves those of us unfamiliar with Arenas feeling as though we have met the real man for the first time. Conversely, one could easily argue Bardem's acting conforms to the limited conventions of American narrative film, thus entailing a "stylized" performance to the same affect as Hillson's definition of Arenas' characterization as being romanticized, or "sanitized" by Schnabel in his film. ${ }^{(43)}$ Indeed, many see the film's stylistic guise as Schnabel's fraudulent and pompous way of tricking film viewers into believing they have experienced cinema belonging to the Art House variety, rather than the Hollywood epic it truly is. ${ }^{(4)}$ Academic writer Jacqueline Loss explains, "Keenly aware of independent film viewers' threshold for representations of the erotic, Before Night Falls simultaneously plays into a dominant model of globalizing society, carves out a negligible space from which it resists that model, and reenacts the same process that it purports to critique."(45)

Basquiat was a painter, Arenas a poet, and although Schnabel provides ample visual cues to reinforce the identity of his characters, the importance and dynamics of both men's work are not sufficiently represented in Schnabel's filmmaking. Just as Ricard's writing in Basquiat becomes symbiotic within the narrative, so too does Arenas' poetry in Before Night Falls, yet neither piece of literature feels truly justified nor authentic in their filmic re-representation, and they both unfairly fall victim to Schnabel's underdeveloped yet emphatic brand of re-appropriation. Scholar Darren J. Davis explains, "The film ends with a Spanish and English version of the poem 'Yo soy' that emphasizes Arenas' belief that he would always be that child 'of always,' but the significance of these words is not particularly developed throughout the film."(46) Seduced into tampering with Arenas' memoirs, it is as if Schnabel's thirst to manipulate primary literary sources is unquenchable.

As a whole, Before Night Falls contributes to an uninformed representation of Arenas rather than a misinformed one, and this is largely due to the filmmaker's ignoring of some of the vital moments that shaped 


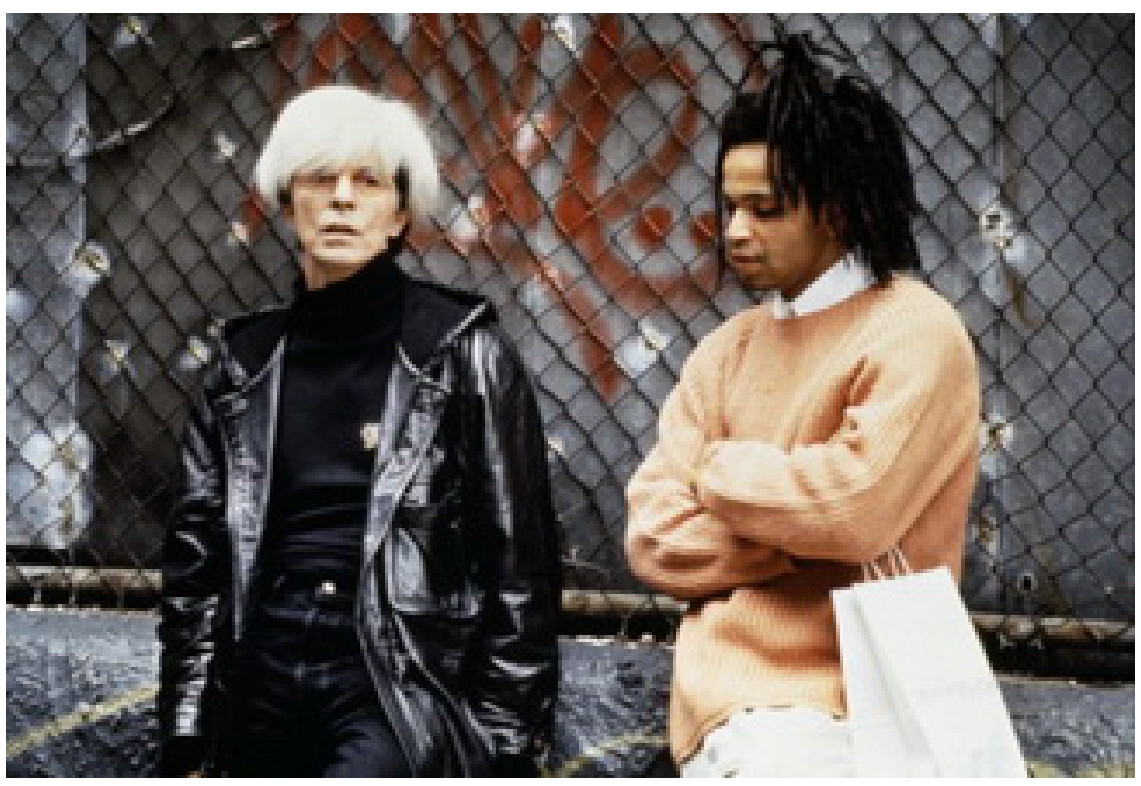

Figure 2: D. Bowie as A. Warhol and J. Wright as Basquiat in Basquiat (Julian Schnabel, 1996)

Arenas' life. First and foremost, Arenas will always be remembered as one of the greatest writers to come from revolution years Cuba, yet those closest to the man insist no passion dominated his lifestyle more than passive sex. ${ }^{(47)}$ Schnabel does his best to illustrate the accelerated promiscuity of Arenas' character, providing glimpses of romantic exchanges we believe to be indicative of reality, yet overall the extent of Arenas' addiction is by no means fulfilled in Before Night Falls. Davis elaborates, "Schnabel deals candidly with Arenas' homosexuality and includes an important scene in which Arenas declares that sex became a way of fighting repression, 'a weapon to use against the regime.'

Yet in the film Arenas' voracious sexual appetite and prolific sexual activity from the time he was a child in the countryside until his death becomes secondary to his artistic nature." (48) Perhaps Schnabel purposefully downplayed this side to Arenas out of respect for the man's privacy, yet Arenas' homosexuality and sexual escapades were already very much common knowledge before the film's release, Arenas himself offers numerous detailed recollections of his encounters in his writing, and it is more likely Schnabel feared having his film labelled as "Gay Cinema" if more graphic scenes or language were deployed. After all, we are talking about a Hollywood film.

Once Bardem and Schnabel's Arenas survives Before Night Falls' Cuban turmoil, we are transported to New York City where we experience the brief and unceremonious death of the poet as he grows sicker and sicker from a disease we assume to be sexually transmitted. Oddly, Schnabel skips entirely Arenas' arrival in Miami, where he lived shortly before heading to New York. Reviewer Davis purports, "Schnabel's treatment of Arenas' life in New York is not as visually or emotionally compelling as the early parts in Cuba. In the film, Arenas lives a subdued life until his eventual death in 1990. In fact, Arenas experienced the wonders and dangers of New York for almost a decade, and he wrote about many of them." (49) Davis' criticism is warranted, for as Arenas edited the majority of his memoirs from his apartment in New York, one would expect Schnabel to devote more of his narrative to reenacting this final chapter in Arenas life, especially since his later writings convey a perplexed interpretation of North American society. ${ }^{(50)}$

Researcher Laurie Vickroy unknowingly supports the structuring of Before Night Falls' narrative, stating, "Arenas is guided by an obsession with the past, which can be gauged by how only 32 out of 317 pages of his autobiography cover the final 10 years of his life, indicating a more powerful relation to his Cuban past than his present or future."(51) Unlike Schnabel's first film Basquiat, we are able to rate the accuracy of the Schnabel's adaptation by simply consulting the original source of inspiration: Arenas' memoirs. Observing scholarly discussions about the film, the majority of writers are unimpressed with Schnabel's revised and 
"sanitized" filmic representation of Arenas, yet on the other hand, few are willing to dismiss the work as a bad film, and most have paradoxically come to appreciate the cultural and historic diffusion offered by Schnabel's problematic re-appropriations in his filmmaking.

\section{The Diving Bell and the Butterfly}

Nearing the conclusion of our discussion, we will now examine Schnabel's very popular and most recent narrative film, The Diving Bell and the Butterfly. In terms of characterization, The Diving Bell provides by far the most complicated and stylized protagonist of Schnabel's three films. Acknowledging yet another adaptation of a literary source to the screen, Schnabel enthusiast Schwartz exclaims the filmmaker "made so fluent a movie out of a book that, on the face of it, hardly seems as if it could be filmed." ${ }^{(52)}$ Perseverant Schnabel succeeds in his continual revisionist mission, and does so with impeccable style, provocatively playing off actor Almaric with camera work and mise-en-scene that produces a realistic portrayal of the late fashion mogul Jean Dominique Bauby, know to his peers as "Jean-Do". Perhaps the most impressive aspect of the Diving Bell is its ability to abstain from any clear shots of the protagonist for the first 45 minutes of the film, instead electing to facilitate its representation of Jean-Do through long takes suggestive of a first person perspective. Subsequently, we experience the narrative as it is recorded through the eyes and narrated by the mind of a man suffering from a serious clinical condition. Like Before Night Falls, The Diving Bell is also taken from the memoirs of a non-fiction individual, and although the former film works hard to immaculately stylize and characterize the life of its protagonist, the latter film's inventive, point of view representation of this final stage in Jean-Do's life undoubtedly stands as Schnabel's foremost achievement as a filmmaker.

However, Schnabel does not deserve all the credit for the Diving Bell's powerful characterization of JeanDo. Almaric's performance in the lead role is executed brilliantly, and it is difficult to imagine another man pulling off such a realistic embodiment of the symptoms that come with paralysis. Captured mainly through close-ups, the facial expressions and body language conveyed by Almaric generate a convincing image of a severely ailing man, his off-screen narration (portraying his stream of consciousness) and our literally eyeball viewpoint of the narrative (in one sequence we experience the excruciating stitching shut of Jean-Do's eyelid through a POV lens) functioning as complimentary motifs in this multi-dimensional characterization. Unexpectedly, The Diving Bell's representation of a character suppressed by physical injury may be the best of its kind in all of film history. However, empathizing with the real life friends and family of the deceased Jean-Do, Schnabel's film is essentially a filmic recollection of the most vital chapter in the man's life, and they understandably find the portrayal of their lost friend controversially distorted and jaded. ${ }^{(53)}$

Regardless of what Oscar or Golden Globe nominations Schnabel's work as a filmmaker is worthy of, the damaging effects of misrepresentation are once again noticeable in the recreation of Jean-Do's identity with The Diving Bell. To the same extent as Before Night Falls, Schnabel takes on Jean-Do's memoirs as his source of narrative inspiration, and judging by reviewer Beth Arnold's research on the film in her internet publication "The Truth About The Diving Bell and the Butterfly", the uproar and dismay projected by those acquainted with the protagonist in real life carries a furious tone greater than that inspired by any Schnabel film to date. ${ }^{(54)}$ Arnold explains, "Bauby's speech therapist, Fichou, didn't return my phone calls for this article. But Marie-Josée Croze, who played her in the movie, was quoted in CanMag.com as saying that Fichou 'didn't like the script ... She said, 'No, it wasn't like that in real life. I remember Jean-Do never said that he wanted to die. She was against lots of stuff in the script."'(55)

Referring to a scene in The Diving Bell where Jean-Do sullenly communicates with his therapist he wishes to be dead (which the therapist appropriately finds upsetting), Arnold's research deems this moment in the film as fictional and fabricated. ${ }^{(56)}$ Supporting Arnold's claims, scholar Judy Goodpasture discusses JeanDo's writing in his original version of The Diving Bell, praising the man for "Never wallowing in self-pity or congratulating himself for his sanity and generosity, he finds bits of life to enjoy and looks forward to what the next day will bring." (57) Coupling this misrepresentation in character with another Jean-Do refers to as "the mother of my children" (for they were never married and no longer together), this woman who in life he hated is treated with a suspicious level of sympathy in the film, and Arnold upholds that Schnabel included Bauby's widow of sorts in the screenwriting process. ${ }^{(58)}$ Therefore, any critical or financial success surrounding the Diving Bell can merely be seen as another typically manipulative conquest by Schnabel, revising the identity of an outstanding man as a means to satisfy his own creative interests. 


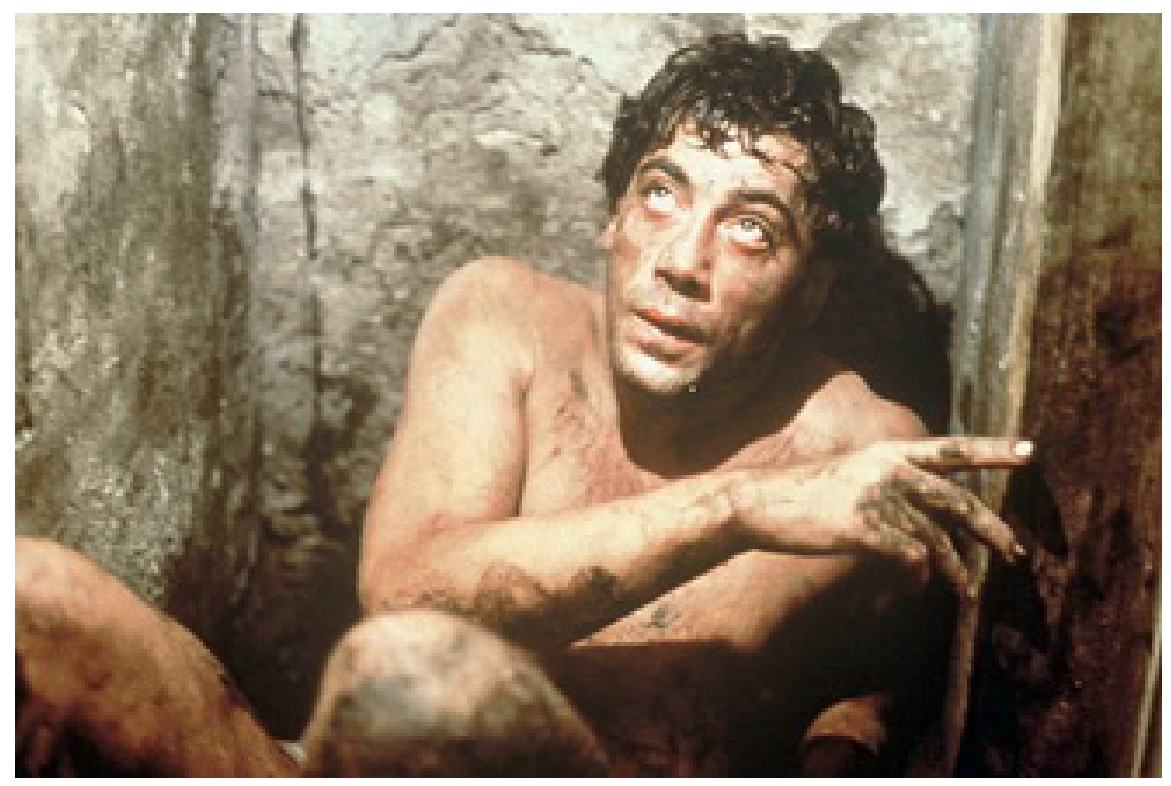

Figure 3: Javier Bardem in Before Night Falls (Julian Schnabel, 2000)

Having taken an expansive look at the strategies that comprise Schnabel's filmmaking, his involvement with work that sees itself as historical and biographical cinema is impossible to ignore. Why is Schnabel so insistent on re-representing the memorable lives of Basquiat, Arenas and Bauby in film? What is increasingly lost in translation is that these films, despite the slippery slope of misrepresentation, have brought the meaningful lives of these three men to the forefront of contemporary culture, and we have Schnabel to thank for making these at times overlooked men accessible to present day audiences internationally. In contrast, even a base level of research and investigation into any of these men's lives and careers beyond Schnabel's silver screen versions awaken the truth behind their corrupted legacies, today diminished to products of Schnabel's cinematic re-appropriations. Browsing through a collection of Schnabel quotations, in one instance the artist explains his fascination with incorporating ready-made objects into the composition of his paintings. ${ }^{(59)}$

Schnabel says, "Using already existing materials establishes a level of ethnographic-ness in the work; I mean it brings a real place and time into the aesthetic reality." ${ }^{60)}$ Indeed, the more we learn of Schnabel's philosophy as a painter the more we understand his agenda as a filmmaker, and perhaps doing his part to revive these nearly forgotten characters in film assist in reconciling his own controversial identity as an artist. Such is the unstable dynamics of Postmodern history, where words like "identity", "representation", "memory" and "history" are constantly suspect and perpetually reevaluated. In closing, Loss suggests how we, researchers and film-goers, can seek a purer form of representation when examining the life of a non-fiction individual:

Schnabel's Before Night Falls takes Arenas to be a vestige of a dying world, one whose dreams reflected at once false and repressive ideologies and the belief in the transcendence of art. Keeping in mind this narrative, it is important to recall the several collections of essays about Arenas that resemble more closely eulogies testifying to the writer's immense being, illustrated with photographs of the writer with his friends. They connect the critics to their object of investigation, and bring readers up close to the faces of Arenas... However, in the Armenian vein of continually questioning the manner by which affiliations are established, the salvation articulated by the film and its director should also be challenged. The narrative, in turn, prompts an evaluation of memory and reminds us of the need to resuscitate what has been less than forgotten. ${ }^{(61)}$ 


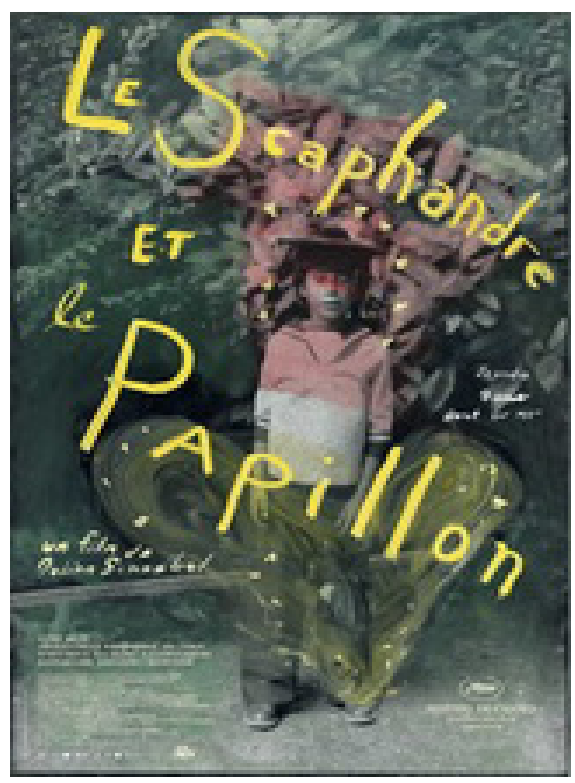

Figure 4: The Diving Bell and the Butterfly (Julian Schnabel, 2007, publicity poster)

\section{Notes}

1. Schwartz, Sanford, "The Nerve and The Will", The New York Review of Books, Vol. 55, No. 3 (Mar., 2008).

2. Foster, Hal, Rosalind Kraus, Yve-Alain Bois, Benjamin Buchloh, Art Since 1900: Volume 2. New York: Thames \& Hudson, 2004.

3. Foster, Hal, Rosalind Kraus, Ye-Alain Bois, Benjamin Buchloh, Art Since 1900: Volume 2. New York: Thames \& Hudson, 2004.

4. Hopkins, David, After Modern Art: 1945-2000. Oxford: Oxford University Press, 2000.

5. Ibid.

6. Ibid.

7. Ricard, Rene, "Not About Julian Schnabel", Artforum, Vol. 19, No. 10 (Summer 1981).

8. Ricard, Rene, "Radiant Child", Artforum, Vol. 20, No. 4 (Dec. 1981).

9. Ibid.

10. Schwartz, Sanford, "The Nerve and The Will", The New York Review of Books, Vol. 55, No. 3 (Mar., 2008).

11. Ibid.

12. Emmerling, Leonhard, Basquiat, Köln: Taschen, 2003.

13. Palmqvist, Anna, ed., Jean-Michel Basquiat, Julian Schnabel, Uddevalla: Bohuslaningens Boktryckeri $\mathrm{AB}, 1989$.

14. Emmerling, Leonhard, Basquiat, Köln: Taschen, 2003.

15. Stavans, Ilan, "Before Night Falls", World Literature Today, Vol. 68, No. 4, Kamau Brathwaite: 1994 
Neustadt.

16. Ibid.

17. Loss, Jacqueline, "Global Arenas: Narrative and Filmic Translation of Identity", Nepantla: Views From South 4.2. Durham: Duke University Press 2003.

18. Ibid.

19. Schwartz, Sanford, "The Nerve and The Will", The New York Review of Books, Vol. 55, No. 3 (Mar., 2008).

20. Ibid.

21. Arnold, Beth, "The Truth About The Diving Bell and The Butterfly", Salon Media Group (2008): 10 Dec. 2009. .

22. Emmerling, Leonhard, Basquiat, Köln: Taschen, 2003.

23. Ibid.

24. Ibid.

25. Bordwell, David, and Kristin Thompson. Film History: An Introduction. New York: McGraw Hill, 2003.

26. Ibid.

27. Schwartz, Sanford, "The Nerve and The Will", The New York Review of Books, Vol. 55, No. 3 (Mar., 2008).

28. Bordwell, David, and Kristin Thompson. Film History: An Introduction. New York: McGraw Hill, 2003

29. Ibid.

30. Emmerling, Leonhard, Basquiat, Köln: Taschen, 2003.

31. Ibid.

32. Ibid.

33. Ibid.

34. Ricard, Rene, "Radiant Child", Artforum, Vol. 20, No. 4 (Dec. 1981).

35. Emmerling, Leonhard, Basquiat, Köln: Taschen, 2003.

36. Ibid.

37. Ibid.

38. Palmqvist, Anna, ed., Jean-Michel Basquiat, Julian Schnabel, Uddevalla: Bohuslaningens Boktryckeri $\mathrm{AB}, 1989$.

39. Emmerling, Leonhard, Basquiat, Köln: Taschen, 2003.

40. Loss, Jacqueline, "Global Arenas: Narrative and Filmic Translation of Identity", Nepantla: Views From South 4.2. Durham: Duke University Press 2003.

41. Bordwell, David, and Kristin Thompson. Film History: An Introduction. New York: McGraw Hill, 2003.

42. Ibid.

43. Loss, Jacqueline, "Global Arenas: Narrative and Filmic Translation of Identity", Nepantla: Views From 
South 4.2. Durham: Duke University Press 2003.

44. Ibid.

45. Ibid.

46. Davis, Darien J., "Before Night Falls", The American Historical Review Vol. 106, No. 4 (Oct., 2001), pp. $1512-1513$.

47. Stavans, Ilan, "Before Night Falls", World Literature Today, Vol. 68, No. 4, Kamau Brathwaite: 1994 Neustadt.

48. Davis, Darien J., "Before Night Falls", The American Historical Review Vol. 106, No. 4 (Oct., 2001), pp. 1512-1513.

49. Ibid.

50. Ibid.

51. Vickroy, Laurie, "The Traumas of Unbelonging: Reinaldo Arenas's Recuperations of Cuba", MELUS, Vol. 30, No. 4, Home: Forged or Forged? (Winter, 2005), pp. 109-128.

52. Schwartz, Sanford, "The Nerve and The Will", The New York Review of Books, Vol. 55, No. 3 (Mar., 2008).

53. Arnold, Beth, "The Truth About The Diving Bell and The Butterfly", Salon Media Group (2008): 10 Dec. 2009. .

54. Ibid.

55. Ibid.

56. Ibid.

57. Goodpasture, Judy, "Flying From Within", The English Journal, Vol. 87, No. 4, Literary Festival (Apr., 1998), pp. 87-88.

58. Arnold, Beth, "The Truth About The Diving Bell and The Butterfly", Salon Media Group (2008): 10 Dec. 2009. .

59. Hollein, Max, ed., Julian Schnabel Paintings: 1978-2003, Ostfildern-Ruit: Hatje Cantz Verlag, 2004.

60. Ibid.

61. Loss, Jacqueline, "Global Arenas: Narrative and Filmic Translation of Identity", Nepantla: Views From South 4.2. Durham: Duke University Press 2003.

\section{References}

\section{Bibliography}

Arenas, Reinaldo, Before Night Falls. New York, New York: Penguin Books Inc., 1993.

Arnold, Beth, "The Truth About The Diving Bell and The Butterfly", Salon Media Group (2008): 10 Dec. 2009. .

Bordwell, David, and Kristin Thompson. Film History: An Introduction. New York: McGraw Hill, 2003.

Davis, Darien J., "Before Night Falls", The American Historical Review Vol. 106, No. 4 (Oct., 2001), pp. 1512-1513.

Dempsey, Amy, Styles, Schools and Movements: The Essential Encyclopaedic Guide to Modern Art. London: Thames \& Hudson, 2002.

Emmerling, Leonhard, Basquiat, Köln: Taschen, 2003. 
Foster, Hal, Rosalind Kraus, Yve-Alain Bois, Benjamin Buchloh, Art Since 1900: Volume 2. New York: Thames \& Hudson, 2004.

Goodpasture, Judy, "Flying From Within", The English Journal, Vol. 87, No. 4, Literary Festival (Apr., 1998), pp. 87-88.

Hainley, Bruce, "Bruce Hainley on Artforum, December 1981", Artforum, Vol. 40, No. 4 (Dec. 2001).

Hassan, Salah D., Introduction: "Origins" of Postmodern Cuba. East Lansing: Michigan State University.

Hollein, Max, ed., Julian Schnabel Paintings: 1978-2003, Ostfildern-Ruit: Hatje Cantz Verlag, 2004.

Hopkins, David, After Modern Art: 1945-2000. Oxford: Oxford University Press, 2000.

Loss, Jacqueline, "Global Arenas: Narrative and Filmic Translation of Identity", Nepantla: Views From South 4.2. Durham: Duke University Press 2003.

Magliozzi, Ron, and Mark Swartz, "Starring MoMA: The Museum of Modern Art on Film", MoMA, Vol. 4, No. 6 (Jul. - Aug., 2001), pp. 31-33.

Ocasio, Rafael, "Gays and the Cuban Revolution: The Case of Reinaldo Arenas", Latin American Perspectives Vol. 29, No. 2, Gender, Sexuality, and Same-Sex Desire in Latin America (Mar., 2002), pp. 78-98.

Palmqvist, Anna, ed., Jean-Michel Basquiat, Julian Schnabel, Uddevalla: Bohuslaningens Boktryckeri AB, 1989.

Ricard, Rene, "Not About Julian Schnabel", Artforum, Vol. 19, No. 10 (Summer 1981).

Ricard, Rene, "Radiant Child", Artforum, Vol. 20, No. 4 (Dec. 1981).

Stavans, Ilan, "Before Night Falls", World Literature Today, Vol. 68, No. 4, Kamau Brathwaite: 1994, Neustadt.

Schwartz, Sanford, "The Nerve and The Will", The New York Review of Books, Vol. 55, No. 3 (Mar., 2008).

Vickroy, Laurie, "The Traumas of Unbelonging: Reinaldo Arenas's Recuperations of Cuba", MELUS, Vol. 30, No. 4, Home: Forged or Forged? (Winter, 2005), pp. 109-128.

\section{Author Information}

Alex BRITTON is a senior Honours Film student at the University of Waterloo. His professional interest concentrates on theoretical aspects of experimental and avant-garde cinema. 